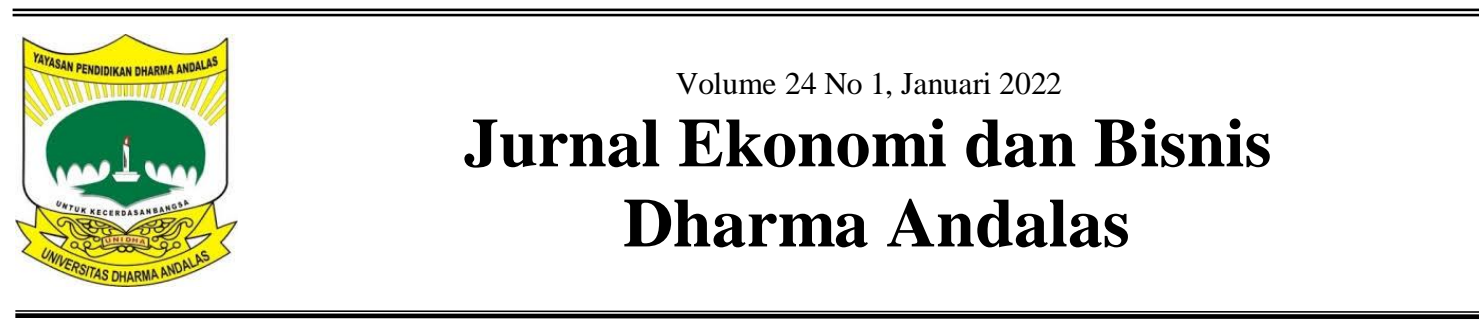

\title{
Perbedaan Underpricing dan Volatilitas Harga Saham Perusahaan yang IPO Sebelum dan Selama Pandemi Covid-19 di Bursa Efek Indonesia
}

\author{
Yolanda Natalia Christine ${ }^{1}$, Cicilia Erna Susilawati ${ }^{2}$, Cyrillius Martono ${ }^{3}$ \\ Fakultas Bisnis Unika Widya Mandala Surabaya ${ }^{1,2,3}$ \\ e-mail:erna-s@ukwms.ac.id
}

\begin{abstract}
The Covid-19 pandemic has affected many aspects, including the capital market. In 2020, during the COVID-19 pandemic, there were 51 companies conducting IPOs. This shows that the company's interest in obtaining funding sources through the stock exchange is still high. This study aims to analyze investor reactions to the IPO before the Covid-19 pandemic. The analysis was carried out by examining the differences in underpricing and stock price volatility in companies conducting IPOs before and during the Covid-19 pandemic. The number of samples of companies that conducted IPOs in 2019 was 55 companies and in 2020 there were 51 companies. The Mann-Whitney T-Test technique was used to determine the difference between underpricing and the Independent Sample T-Test, to determine the difference in trading volatility. The results show that there are differences in underpricing of companies that IPO before and during the Covid-19 pandemic, but the volatility of stock trading is no different.

Keywords: IPO companies; before and during the Covid-19 Pandemi; Underpricing; Stock Price Volatility
\end{abstract}

\begin{abstract}
ABSTRAK
Pandemi Covid-19 merupakan peristiwa yang mempengaruhi berbagai aspek kehidupan, termasuk pasar modal. Tahun 2020, saat pandemi covid 19 sedang terjadi, terdapat 51 perusahaan yang melakukan IPO. Hal ini menunjukkan bahwa minat perusahaan untuk mendapatkan sumber pendanaan melalui bursa saham cukup tinggi. Penelitian ini bertujuan untuk menganalisis reaksi investor terhadap peristiwa IPO sebelum selama pandemi Covid19.Analisis dilakukan dengan menguji perbedaan underpricing dan volatilitas perdagangan saham pada perusahaan yang melakukan IPO sebelum dan selama pandemi Covid-19.Jumlah sampel perusahaan yang melakukan IPO periode 2019 sebanyak 55 perusahaan dan periode 2020 sejumlah 51 perusahaan. Pengujian dilakukan dengan menggunakan teknik uji MannWhitney T-Testuntuk perbedaan underpricingdan Independent Sample T-Test, untuk menguji perbedaan volatilitas perdagangan. Hasil penelitian menunjukkan bahwa terdapat perbedaan underpricing pada perusahaan yang IPO sebelum dan selama Pandemi Covid-19, akan tetapi volatilitas perdagangan sahamnya tidak berbeda.
\end{abstract}

Kata Kunci: perusahaan IPO; sebelum dan selama pandemi Covid-19; underpricing; volatilitas harga saham 


\section{PENDAHULUAN}

Pandemi Covid-19 merupakan peristiwa yang mempengaruhi berbagai aspek kehidupan, termasuk pasar modal. Pasar modal merupakan wahana yang digunakan perusahaanuntuk mendapatkansumber pendanaan dari masyarakat. Initial Public Offering (IPO) merupakan proses pada saat perusahaan melakukan penawaran saham pertama kalinya kepada publik di pasar modal (Alteza, 2005).

Fenomena yang sering terjadi ketika sebuah perusahaan melakukan IPO adalah underpricing.Underpricing terjadi jika harga saham pasar perdana lebih rendah dari harga saham hari pertama saat diperdagangankan di pasar sekunder. Fenomena underpricing tidak menguntungkan bagi perusahaan, karena dana yang diperoleh oleh perusahaan tidak optimal, namun disisi lain ada pihak yang diuntungkan yaituinvestor yang melakukan transaksi di pasar modal, karena investor dapat menikmati initial return dari keuntungan awal pembelian saham(Kurniawan 2006).

Asimetri informasi menjadi salah satu faktor yang menyebabkan terjadinya underpricing (Beatty,1989). Asimetri informasi semakin tinggi pada saat pandemi Covid-19, karena tingginya ketidakpastian ekonomi. Perusahaan dan underwriter merupakan pihak yang terlibat dalam proses menentuan harga saham pada saat IPO, dan tingganya asimetri informasi menjadi salah satu pertimbangan dalam penentuan harga saham perdana. Asimetri informasi dapat terjadi antara dua belah pihak yaitu penjamin emisi dan emiten ataupun dapat diklasifikasikan sebagai kelompok informed investor dan uninformed investor (Beatty, 1989; dalam Kristiantari, 2013).

Adanya perbedaan informasi antara pihak-pihak yang terlibat dalam penawaran perdana yaitu emiten dan penjamin emisi menyebabkan terjadinya asimetri informasi. Asimetri informasi terjadi karena tidak adanya informasi yang lengkap, dapat menyebabkan terjadinya perbedaan harga (Baron, 1982; dalam Kristiantari, 2013). Selama periode 2019-2020, terdapat 106 perusahaan yang melakukan IPO, ditemukan 103 perusahaan mengalami underpricing dan 3 perusahaan mengalami overpricing. Utami (2020) berpendapat bahwa perusahaan yang melakukan IPO pada tahun 2020 lebih rendah dari pada tahun 2019, karena situasi pandemi telah menyebabkan menurunya minat perusahaan untuk melakukan IPO.

Menurut Rock (1986, dalam Kristiantari, 2013) menyatakan bahwa terjadi asimetri informasi antara kelompok investor yang lebih mengetahu informasi dan investor yang kurang mengetahuiinformasi. Dimana pihak investor yang memahami kondisi pasar dapat mempelajari lebih lanjut perihal prospek bahwa perusahaan dapat membeli saham IPO jika harga pasar yang diharapkan melebihi harga awal. Pada saat yang sama, kelompok investor yang kurang informasi atau memiliki informasi yang sedikit diketahui, oleh karena itu dapat membuat penawaran secara semaunya, bahkan untuk saham yang underpriced maupun overpriced pada saat IPO dibursa saham.

Di masa depan, kelompok investor yang kurang informasi mungkin memiliki proporsi yang lebih tinggi dari saham IPO yang overpriced daripada kelompok investor dengan informasi yang lebih. Banyak kelompok investor yang tidak memiliki informasi dengan baik memilih untuk meninggalkan pasar perdana karena menyadari bahwa calon investor menerima jumlah saham yang tidak proporsional. Apabila penawaran umum perdana (Initial Public Offering) memiliki harga yang sama atau harga 
yang murah dapat memungkinkan kelompok tersebut berpartisipasi di pasar perdana sehingga dapat memperoleh imbal/pengembalian saham yang wajar dan dapat menutupi kerugian akibat pembelian saham yang terlalu mahal.

Selain underpricing fenomena yang muncul pada peristiwa IPO menurut Kartika (2010) adalah volatilitas harga saham setelah perusahaan pelakukan IPO. Volatilitas harga saham akan meningkatkan risiko ketidakpastian bagi investor, sehingga mengurangi minta investor untuk melakukan transaksi pada saham-saham perusahaan yang baru saja melakukan IPO. Pandemi berdampak besar pada volatilitas harga saham, penurunan harga saham secara tajam, menyebabkan perbedaan yang sangat besar antara harga terendah dan harga tertinggi secara bersamaan. Kharisma (2020) menyatakan bahwabagi sebagian investor, koreksi merupakan kerugian kecil, karena investor percaya bahwa pasar pasti akan kembali ke keadaan sebelumnya. Menurut Prasetyo (2019), ketika harga saham turun, investor bisa menyesuaikan pasar melalui strategi pembelian saham secara bertahap agar pemegang saham tidak kehabisan dana saat pasar masih lemah.

Penelitian Rianty N \& Riana(2020)menunjukkan bahwa perbedaan kepentingan pihak emiten dan underwriter mengakibatkan terjadinya fenomena underpricing yang disebabkan karena adanya asimetri informasi. Underwriter akan melakukan underpricinguntuk memperkecil risiko kemungkinan bahwa saham yang ditawarkan tidak dimintai investor. Sedangkan penelitian Widhawati \& Panjaitan(2013) menunjukkan bahwa perusahaan yang IPO akan mengalami underpricing dengan ditandai adanya nilai return yang positif. Investor akan mendapatkan keuntungan yang lebih tinggi pada investasi jangka pendek daripada investasi jangka panjang.

Penelitian yang berkaitan dengan volatilitas harga saham dilakukan oleh Hutauruk (2021) yang hasilnya menunjukkan terjadinya perbedaan volatilitas harga saham LQ 45 pada situasi sebelum dan sesudah terjadinya Pandemi Covid-19.

Fenomena yang terjadi di BEI menunjukkan bahwa sebelum pandemi tingkat underpricing dan volatilitas harga saham perusahaan yang melakukan IPO relatif rendah, karena situasi perekonomian pada saat itu lebih stabil dan asimetri informasi antar pelaku pasar lebih kecil. Sedangkan, selama pandemi, tingkat underpricing dan volatilitas saham tinggi, karena situasi yang tidak stabil, informasi tidak merata, menyebabkan terjadinya asimetri informasi yang tinggi. Perusahaan yang IPO selama pandemi menetapkan harga yang underpriced sebagai kompensasi bagi investor agar tetap berpartisipasi untuk membeli saham pada saat IPO.

Berdasarkan fenomena dan beberapa temuan dari penelitian terdahulu tersebut diatas maka penelitian ini bertujuan untuk menganalisis perbedaan underpricing dan volatilitas harga saham perusahaan yang melakukan IPO sebelum dan selama pandemic Covid-19.

Wong, WB, and Ting (2017) melakukan penelitian menunjukkan bahwa terdapat hubungan negatif antara initial market adjusted return dan return yang disesuaikan pasar awal selama periode 36 bulan. Dalam penelitiannya menganalisis keberadaan dan besarnya fenomena underpricing dan kinerja pasca pencatatan IPO yang terdaftar di Bursa Malaysia dan bertujuan untuk memberikan wawasan terutama tentang hubungan antara IPO awal dan panjang kinerja saham jangka dan empat penentu utama yang mempengaruhi 
underpricing, yaitu ukuran IPO, volatilitas pasar, status penjamin emisi dan kebalikan dari harga IPO. Informasi ini digunakan investor untuk melihat kondisi suatu emiten dalam jangka panjang. Sebelum pandemi, kondisi masih stabil karena informasi yang diperoleh lebih merata yang membuat tingkat underpricing di Indonesia lebih rendah.

Asimetri informasi muncul karena informasi yang diperoleh tidak merata. Selama pandemi informasi yang diperoleh tidak merata, membuat kondisi menjadi tidak stabil sehingga tingkat underpricing itu lebih tinggi daripada sebelum pandemi. Penelitian ini diharapkan bisa menjadi sebuah penelitian yang mendasari dugaan sementara bahwa terdapat perbedaan underpricing perusahaan yang IPO sebelum dan selama pandemi Covid-19 di BEI.

Selain itu (Hutauruk 2021) dalam penelitiannya menunjukkan bahwa terdapat perbedaan pada situasi sebelum dan sesudah terjadinya Pandemi Covid19 terhadap volatilitas harga saham perusahaan LQ45 di BEI. Secara umum telah terjadi penurunan harga saham LQ45 di Bursa Efek Indonesia setelah terjadinya pandemi di tahun 2020 dibandingkan dengan sebelum terjadinya situasi pandemi COVID-19 pada tahun 2019.

Situasi pandemi menyebabkan terjadinya penurunan harga saham. Pandemi covid-19 memiliki dampak yang besar pada perekonomian Indonesia, dimana harga saham mengalami penurunan yang mengakibatkan volatilitas harga saham lebih tinggi dibandingkan sebelum pandemi. Penurunan harga saham selama pandemi diakibatkan karena asimetri informasi sehingga investorperlu mempertimbangkan keputusan investasi yang tepat di masa mendatang.
Berdasarkan fenomena itu maka diduga terdapat perbedaan volatilitas harga saham perusahaan yang IPO sebelum dan selama pandemi Covid-19 di BEI.

\section{METODE PENELITIAN \\ Data dan Sampel}

Penelitian ini menggunakan sampel perusahaan yang melakukan IPO pada periode sebelum pandemi yaitu tahun 2019 dan periode setelah pandemi yaitu tahun 2020 dengan kriteria pada saat IPO perusahaan tersebut mengalami underpricingdi pasar sekunder. Berdasarkan kriteria tersebut terdapat 55 perusahaan sampel sebelum pandemi dan 51 perusahaan setelah pandemi.

Data diambil dari situs www.idx.co.id untuk mendapatkan data perusahaan yang melakukan IPO, data harga perdana dan harga penutupan hari pertama perdagangan di pasar sekunder.

\section{Definisi Operasional dan Pengukuran Variabel}

\section{Initial return (IR)}

Initial return merupakan selisih antara harga penawaran perdana dengan harga penutupan di hari pertama saham diperdagangkan di pasar sekunder. Bila harga perdana lebih rendah daripada harga penutupan maka terjadi underpricing dan jika sebaliknya berarti terjadi overpricing.

$I R=\frac{P_{1}-P_{0}}{P_{0}}$

dimana

IR : Initial return

$\mathrm{P}_{1}$ : Harga penutupan hari pertama di pasar sekunder

$\mathrm{P}_{0}$ : Harga penawaran perdana

Underpricing : IR $>0$

Overpricing : IR $<0$

2. Volatilitas Harga Saham (Vol)

Volatilitas harga saham merupakan pergerakan naik turunnya harga saham di di bursa efek setelah 
perusahaan melakukan IPO. Volatilitas harga saham diukur menggunakan metode Baskin (1989) dengan rumus:

Vol $=\frac{1}{n} \sum \ln \left(\frac{H_{t}}{L_{t}}\right)^{2}$

Dimana:

Vol: Volatilitas Harga saham setelah melakukan IPO

$\mathrm{H}_{\mathrm{t}}$ : Harga tertinggi pada hari ke $\mathrm{t}$

$\mathrm{L}_{\mathrm{t}}$ : Harga terendah pada hari ke $\mathrm{t}$

$\mathrm{n}$ : jumlah observasi. Dalam penelitian ini menggunakan 30 hari perdagangan setelah IPO

\section{Alat analisis Data}

Data IR yang underpriced dan VOL dianalisis menggunakan uji beda sampel independen Sebelum dilakukan uji beda terlebih dahulu dilakukan uji normalitas data. Uji normalitas merupakan persyaratan sebelum uji beda dilakukan. Uji Normalitas dilakukan menggunakan uji kolmogorov smirnov. Apabila data terditribusi normal maka selanjutnya dilakukan uji independen sample $\mathrm{t}$ test akan tetapi jika tidak normal maka digunakan uji beda menggunakan statistik non parametrik yaitu uji Mann-Whitney T-Test.

\section{HASIL DAN PEMBAHASAN}

\section{Statistik Deskriptif}

Gambaran umum dari data Initial return (IR) dan volatilitas harga saham (VOL) pada perusahaan yang IPO sebelum dan selama pandemi covid-19 ditunjukkan pada Tabel 1.

\section{Tabel.1}

Deskripsi data Initial return dan Volatilitas Harga Saham Perusahaan yang IPO sebelum dan selama pandemi Covid 19

\begin{tabular}{ccccc}
\hline Keterangan & \multicolumn{2}{c}{ Initial Return } & Volatilitas Harga Saham \\
\cline { 2 - 5 } & $\begin{array}{l}\text { Sebelum } \\
\text { pandemi }\end{array}$ & $\begin{array}{c}\text { Selama } \\
\text { pandemi }\end{array}$ & $\begin{array}{c}\text { Sebelum } \\
\text { pandemic }\end{array}$ & $\begin{array}{c}\text { Selama } \\
\text { pandemi }\end{array}$ \\
\hline
\end{tabular}

\begin{tabular}{ccccc}
\hline Keterangan & \multicolumn{2}{c}{ Initial Return } & \multicolumn{2}{c}{ Volatilitas Harga Saham } \\
\cline { 2 - 5 } & $\begin{array}{c}\text { Sebelum } \\
\text { pandemi }\end{array}$ & $\begin{array}{c}\text { Selama } \\
\text { pandemi }\end{array}$ & $\begin{array}{c}\text { Sebelum } \\
\text { pandemic }\end{array}$ & $\begin{array}{c}\text { Selama } \\
\text { pandemi }\end{array}$ \\
\hline $\mathbf{N}$ & 55 & 51 & 55 & 51 \\
Minimum & -0.133 & 0.005 & 0.167 & 0.139 \\
Maximum & 0.700 & 0.700 & 0.697 & 0.602 \\
Mean & 0.496 & 0.386 & 0.409 & 0.406 \\
$\begin{array}{c}\text { Std. } \\
\text { Deviation }\end{array}$ & 0.236 & 0.200 & 0.111 & 0.088 \\
\hline Sumber: & & & & \\
\hline
\end{tabular}

Sumber: data diolah (2021)

Tabel 1 menunjukkan bahwa initial return nilai minimum -0.13333 pada PT Bhakti Agung Propertindo Tbk (BAPI) pada tahun 2019 dan 0.00510 pada PT Cipta Selera Murni Tbk (CSMI) pada tahun 2020, sedangkan perusahaan tahun 2019 dan 2020 dengan nilai maksimum yang sama sebesar 0.70000 terjadi pada beberapa perusahaan. Nilai rata-rata (mean) initial return untuk tahun 2019 dan 2020 adalah 0.49582 dan 0.38589 , standar deviasi sebesar 0.23651 dan 0.20057. Hal ini menunjukkan bahwa nilai standar deviasi lebih kecil dari nilai rata-rata, yang berarti initial return relatif homogen/seragam dan tidak berfluktuasi.

Sedangkan data volatilitas harga saham dengan nilai minimum sebesar 0.16755 pada PT Asuransi Jiwa Sinarmas MSIG Tbk (LIFE) pada tahun 2019 dan 0.13897 PT Djasa Ubersakti Tbk (PTDU) tahun 2020, sedangkan nilai maksimum sebesar 0.69757 terjadi pada PT Bima Sakti Pertiwi Tbk (PAMG) tahun 2019 dan 0.60198 terjadi pada PT Royalindo Investa Wijaya Tbk (INDO). Nilai rata-rata (mean) volatilitas harga saham tahun 2019 dan 2020 adalah 0.40888 dan 0.40653 , standar deviasi 0.11134 dan 0.08859. Hal ini menunjukkan bahwa nilai standar deviasi ini lebih kecil dari nilai mean, yang berarti bahwa volatilitas harga saham relatif homogen atau seragam dan tidak berfluktuasi. 


\section{b. Hasil Uji Normalitas Data}

Selanjutnya dilakukan uji normalitas data yang hasilnya ditunjukkan pada tabel 2

Tabel.2

Hasil Uji NormalitasInitial return dan Volatilitas Harga Saham Perusahaan yang IPO sebelum dan selama pandemi Covid 19

\begin{tabular}{ccccc}
\hline \multirow{2}{*}{ Keterangan } & \multicolumn{2}{c}{ Initial Return } & \multicolumn{2}{c}{ Volatilitas Harga Saham } \\
\cline { 2 - 5 } & $\begin{array}{c}\text { Sebelum } \\
\text { pandemic }\end{array}$ & $\begin{array}{c}\text { Selama } \\
\text { pandemi }\end{array}$ & $\begin{array}{c}\text { Sebelum } \\
\text { pandemi }\end{array}$ & $\begin{array}{c}\text { Selama } \\
\text { pandemic }\end{array}$ \\
\hline $\begin{array}{c}\text { Monte } \\
\text { Carlo Sig. } \\
\text { (2-tailed) }\end{array}$ & 0.000 & 0.000 & 0.908 & 0.880 \\
\hline \multirow{4}{*}{ Kesimpulan } & $\begin{array}{c}\text { Data tidak } \\
\text { berdistribusi berdistribusi } \\
\text { normal }\end{array}$ & normal & $\begin{array}{c}\text { Derdistribu } \\
\text { si normal }\end{array}$ & $\begin{array}{c}\text { Data } \\
\text { berdistribusi } \\
\text { Normal }\end{array}$ \\
\hline
\end{tabular}

Sumber: data diolah (2021)

\section{Berdasarkan} pengujian

normalitas menggunakan uji Kolmogorov-Smirnov, diperoleh nilai Monte Carlo. Sig. (2-tailed)untuk data IR adalah 0.000 kurang dari $\alpha=0.05$. Artinya data tidak berdistribusi normal, meskipun data telah ditransformasi dan outlier menunjukkan bahwa data tidak berdistribusi normal, sehingga uji beda dilakukan dengan menggunakan statistik non parametrik yaitu Mann-Whitney TTest. Hasil pengujiannya dapat ditunjukkan pada tabel 3.

Sedangkan untuk uji normalitas data Volatilitas harga, dari tabel 2 dapat diketahui bahwa nilai Montel Carlo. Sig. (2-tailed) sebesar 0.908 sebelum pandemi dan 0.880 selama pandemi nilai ini jauh di atas $\alpha=0.05$. Artinya data berdistribusi normal. Sehingga uji beda volatilitas harga dilakukan menggunakan statistik parametrik Independen Sample T Test

\section{Hasil Uji Beda}

Uji beda rata-rata IR dilakukan menggunakan Mann-Whitney T-Test dikarenakan data tidak terdistribusi normal. Hasil pengujian dapat ditunjukkan pada tabel 3 berikut ini.

\section{Tabel.3}

Hasil Uji Beda Initial return

Perusahaan yang IPO sebelum dan selama pandemi Covid-19

\begin{tabular}{ccc}
\hline \multirow{2}{*}{ Keterangan } & \multicolumn{2}{c}{ Initial Return } \\
& $\begin{array}{c}\text { Sebelum } \\
\text { pandemi }\end{array}$ & $\begin{array}{c}\text { Selama } \\
\text { pandemi }\end{array}$ \\
\hline Asymp. Sig. (2-tailed) & 0.006 \\
$\mathrm{Z}$ & -2.724 \\
\hline
\end{tabular}

Sumber: data diolah (2021)

Berdasarkan tabel diatas diperoleh nilai $\mathrm{Z}$ sebesar -2.724 (data ekstrem) dengan nilai Asymp. Sig. (2tailed) sebesar 0.006 berada di bawah sig $\alpha=5 \%$, sehingga dapat disimpulkan bahwa Terdapat perbedaan yang signifikan pada Initial return pada perusahaan yang IPO sebelum dan selama Pandemi Covid-19 di BEI. Hal ini berarti initial return yang terjadi pada saham-saham yang IPO sebelum dan selama pandemi berbeda secara signifikan, yang terlihat dari rata-rata initial return pada periode sebelum pandemi lebih besar dibandingkan dengan initial return selama pandemi Covid-19.

Sedangkan perbedaan Volatilitas harga saham perusahan yang IPO sebelum dan selama pandemi Covid-19 dilakukan menggunakan uji beda Independen sample $t$ test karena data berdistribusi normal dan hasilnya sebagai berikut:

\section{Tabel.4}

Hasil Independen sample $t$ test

Volatilitas Harga Saham perusahaan yang IPO sebelum dan selamaPandemi Covid-19

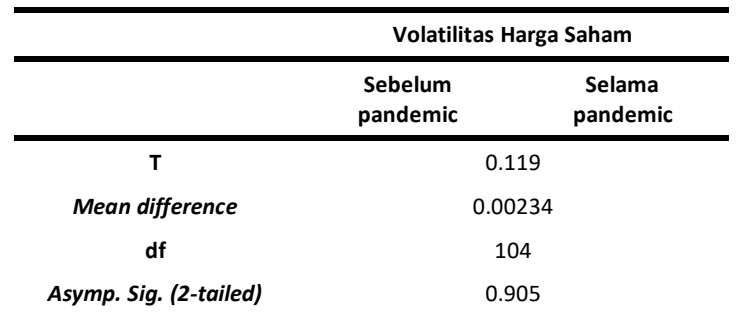

Sumber: data diolah (2021) 
Pada tabel 4 adalah hasil uji beda menggunakan Independent Sample $t$ Test. Nilai $\mathrm{t}$ hitung 0.119 , mean difference merupakan selisih rata-rata volatilitas harga saham sebelum dan selama pandemi Covid-19, Asymp. Sig. (2-tailed) volatilitas harga saham adalah 0.905 lebih tinggi dari nilai sig $\alpha=5 \%$, sehingga dapat disimpulkan bahwa tidak terdapat perbedaan volatilitas harga saham perusahaan yang IPO sebelum dan selama pandemi Covid-19 di BEI. Hasil ini juga terlihat dari data deskripsi statistik (tabel 1) yang menunjukkan bahwa rata-rata volatilitas harga 30 hari setelah IPO pada periode sebelum dan selama pandemi tidak jauh berbeda. Hasil pengujian menggunakan independen sample t test pengkonfirmasi hal tersebut, bahwa tidak terdapat perbedaan volatilitas harga saham pada perusahaan yang IPO sebelum dan selama pandemi covid-19.

\section{Pembahasan}

Hasil data menunjukkan bahwa terdapat perbedaan IR pada perusahan yang underpricing saat IPO sebelum dan selama pandemi Covid-19. Artinya perusahaan yang berkualitas baik akan akan menetapkan harga yang underpriceduntuk memberikan sinyal bahwa perusahaan tersebut merupakan perusahaan dengan prospek yang baik sehingga pada saat IPO saham perusahaan memiliki nilai pasar yang tinggi. Perusahaan dengan kualitas baik akan menjadi pertimbangan investor untuk melakukan investasi pada perusahaan yang melakukan IPO. Sebelum pandemi, tingkat underpricing lebih tinggi dibandingkan selama pandemi covid-19. Artinya investor menerima keuntungan yang lebih tinggi sebelum pandemi dibandingkan setelah pandemi.

Hasil ini sejalan dengan hasil penelitian Rianty dan Riana (2020), variabel reputasi penjamin emisi dan auditor berpengaruh signifikan terhadap underpricing dan konsisten dengan teori asimetri informasi dan teori sinyal.Teori asimetri informasi menetapkan bahwa perbedaan informasi antara emiten dan penjamin emisi merupakan salah satu penyebab terjadinya underpricing. Penelitian ini juga sejalan dengan Widhawati \& Panjaitan, (2013) menunjukkan bahwa terdapat perbedaan short-term underpricing dengan saham perusahaan BUMN dan BUMS yang melakukan IPO. Hasil penelitian ini tidak konsisten dengan Wong et al. (2017) yang menunjukkan bahwa terdapat hubungan negatif antara initial market adjusted return dan return yang disesuaikan pasar awal selama periode 36 bulan.

Hasil olah data pada pengujian perbedaan volatilitas harga saham sebelum dan selama pandemi Covid-19 menunjukkan bahwa tidak terdapat perbedaan volatilitas harga saham perusahaan yang IPO sebelum dan selama pandemi Covid-19. Artinya meskipun selama pandemi asimetri informasi cukup tinggi akan tetapi harga saham selama 30 hari pengamatan setelah IPO tidak lebih fluktuatif dibandingkan sebelum pandemi. Alasan lainnya adalah kemampuan perusahaan yang IPO di BEI tidak diragukan lagi oleh investor untuk mendapatkan return yang tinggi walaupun dalam kondisi yang tidak pasti dan perusahaan yang IPO di BEI mendapatkan kepercayaan secara langsung dari investor serta investor sudah siap untuk menghadapi adaya fluktuasi harga saham dengan menggunakan informasi sebagai acuan untuk pengambilan keputusan.

Teori asimetri informasi
mengemukakan bahwa perbedaan
informasi merupakan salah satu
penyebab terjadinya underpricing.
Semakin tinggi asimetri informasi yang
terjadi akan menyebabkan underpricing


yang lebih tinggi juga. Akibatnya, investor akan membeli saham IPO yang overpriced karena investor memiliki informasi dan membeli saat harganya underpricing. Sebaliknya, jika investor tidak mendapat informasi, ketika membeli saham saat harga saham dibawah, investor akan mendapatkan saham yang tidak sesuai, sehingga kelompok yang kurang informasi cenderung meninggalkan pasar perdana.

Perusahaan dengan kualitas tinggi lebih menyukai tingkat underpricing yang tinggi sebagai sinyal bahwa perusahaannya merupakan perusahaan dengan prospek yang baik, sehingga pada saat IPO saham perusahaan memiliki nilai pasar yang tinggi. Kualitas yang tinggi akan mempengaruhi investor di pasar terhadap nilai perusahaan yang menentukan jumlah investasi yang akan dijual pada penawaran berikutnya.

Akan tetapi hasil penelitian ini tidak konsisten dengan Wong et al. (2017) yang menunjukkan bahwa terdapat hubungan negatif antara initial market adjusted return dan return yang disesuaikan pasar awal selama periode 36 bulan.

Hasil penelitian ini juga menunjukkan bahwa tidak terdapat perbedaan volatilitas harga saham pada perusahaan yang IPO sebelum dan selama pandemi Covid-19 di BEI. Selama pandemi, harga saham cenderung berfluktuasi dan merugikan investor, tetapi selama pandemi harga saham mengalami perbaikan sedikit demi sedikit harga saham di setiap perusahaan yang IPO. Walaupun informasi yang tersebar tidak merata, karena pergerakan harga saham selalu berubah tetapi tidak dapat digunakan sebagai alat untuk memprediksi volatilitas harga saham di masa mendatang. Selain itu kemampuan perusahaan yang IPO di BEI tidak diragukan lagi oleh investor untuk mendapatkan return yang tinggi sehingga meskipun dalam kondisi yang tidak pasti dan perusahaan yang tidak terlalu beresiko pada saat IPO masih mendapatkan kepercayaan langsung dari investor. Investor sudah mempersiapkan diri untuk menghadapi adaya fluktuasi harga saham dengan menggunakan informasi sebagai acuan untuk pengambilan keputusan.

Penelitian ini mendukung penelitian terdahulu yang dilakukan oleh Jannah and Haridhi (2016) mendapati hasil yang signifikan bahwa dividend payout dan volume perdagangan tidak mempengaruhi volatilitas harga saham. Penelitian lainnya adalah Khurniaji dan Raharja (2013) mendapati hasil yang signifikan bahwa dividen yield serta dividend payout ratio tidak mempengaruhi volatilitas harga saham.

Penelitian ini tidak konsisten dengan penelitian Hugida (2011) menunjukkan bahwa penggunaan variabel yang berkaitan dengan volume perdagangan, inflasi, dan nilai tukar berpengaruh signifikan terhadap volatilitas harga saham. Penelitian Hutauruk, (2021) juga menunjukkan bahwa terdapat perbedaan pada situasi sebelum dan sesudah terjadinya Pandemi Covid-19 pada volatilitas harga saham LQ45 di BEI.

\section{SIMPULAN}

Berdasarkan hasil analisis data disimpulkan bahwa terdapat perbedaan Underpricing pada perusahaan yang melakukan IPO sebelum dan selama pandemi covid-19. Underpricing sebelum pandemi lebih besar daripada setelah pandemi. Perbedaan ini dimungkinkan karena selama pandemi terdapat ketidakpastian yang tinggi sehingga perusahaan yang melakukan IPO cenderung menetapkan harga perdana pada harga wajar. Sebelum 
pandemi, tingkat underpricing lebih tinggi dan investor mendapatkan keuntungan yang lebih besar dibandingkan pada saat pandemi. Sedangkan selama pandemi pada perusahaan yang melakukan IPO tetap terjadi underpricing meskipun lebih rendah daripada sebelum pandemi. Sehingga baik sebelum pandemi aupun setelah pandemi Covid-19, tetap terdapat underpricing pada perusahaan yang melakukan IPO.

Meskipun begitu volatilitas harga saham selama 30 hari pengamatan setelah IPO, tidak berbeda antara sebelum dan selama pandemi Covid 19. Hal ini dimungkinkan karena investor tidak bereaksi berlebihan terhadap peristiwa IPO meskipun masih dalam suasana pandemi Covid-19. Investor cepat beradaptasi dengan kondisi perekonomian yang terdampak peristiwa covid-19 dan harga saham perusahaanperusahaan yang IPO diperdagangankan dengan fluktuasi yang tidak berbeda dengan periode sebelum pandemi.

\section{UCAPAN TERIMA KASIH}

Penulis mengucapkan terima kasih kepada Universitas Katolik Widya Mandala Surabaya yang telah memfasilitasi sehingga penelitian ini dapat terselesaikan dengan baik.

\section{DAFTAR PUSTAKA}

Anon. 2005. "Muniya Alteza." Pengaruh Likuiditas Terhadap Underpricing Saham Perdana 3.

Baron, David P. 1982. "A Model of the Demand for Investment Banking Advising and Distribution Services for New Issues." The Journal of Finance Vol. 37(No. 4):955-76.

Beatty, Randolph P. 1989. "Pricing." Auditor Reputation and the Pricing of Initial Public Offerings 64(4):693-709.

Hugida, Lydianita. 2011. “Analisis
Faktor-Faktor Yang Mempengaruhi Volatilitas Harga SAHAM." 3(2):152-71.

Hutauruk, Martinus Robert. 2021. "Dampak Sebelum Dan Sesudah Pandemi COVID-19 Terhadap Harga Saham LQ45 Di Bursa Efek Indonesia." Jurnal Riset Akuntansi Dan Keuangan 9(2):241-52.

Jannah, Raudhatul and Musfiari Haridhi. 2016. "Pengaruh Kebijakan Dividen, Earning Volatility, Dan Leverage Terhadap Volatilitas Harga Saham Pada Perusahaan Non-Financing Yang Terdaftar Di Bursa Efek Indonesia Tahun 20102014." Jurnal Ilmiah Mahasiswa Ekonomi Akuntansi 1(1):133-48.

Kartika, Andi. 2010. "Di Indonesia Dan Malaysia." Aset 12(1):17-26.

Kharisma, Dewi. 2020. "Apa Itu Koreksi Dan Apa Pengaruhnya Terhadap Investasi Kamu?" Pluang.Com.

Khurniaji, Andreas Widhi and Surya Raharja. 2013. "Hubungan Kebijakan Dividen (Dividend Payout Ratio Dan Dividend Yield) Terhadap Volatilitas Harga Saham Di Perusahaan-Perusahaan Yang Terdaftar Di Bursa Efek Indonesia." Diponegoro Journal of Accounting $0(0): 113-22$.

Kristiantari, I. Dewa Ayu. 2013. "Analisis Faktor - Faktor Yang Mempengaruhi Underpricing Saham Pada Saat Penawaran Perdana Di Bursa Efek Indonesia." Jurnal Ilmiah Akuntansi Dan Humanika 53(9):1689-99.

Kurniawan, Benny. 2006. "Analisis Pengaruh Variabel Keuangan Dan Non Keuangan Terhadap Initial Return Dan Return 7 Hari Setelah Initial Public Offering (IPO) (Studi Empiris: Di Perusahaan Non Keuangan Yang Listing Di BEJ Periode 2002-2006)." Tesis Magister Manajemen UNDIP Yang 
Dipublikasikan.

Prasetyo, Herry. 2019. "Manfaatkan

Peluang Koreksi Pasar, Investor Bisa Mencicil Beli Saham." Insight.Kontan.Co.Id.

Rianty N, Martha and Dwi Riana. 2020. "Pengaruh Variabel Keuangan Dan Non Keuangan Terhadap Underpricing Pada Perusahaan Yang Melakukan Initial Public Offering (IPO) Di Bursa Efek Indonesia." Akuntansi Dan Manajemen 15(1):42-54.

Utami, Dhiany Nadya. 2020. "BEI Ungkap Alasan Minat IPO Masih Tinggi Di Tengah Pandemi." Market.Bisnis.Com.

Widhawati, Indira Rully and L. Yunia Panjaitan. 2013. "Analisis Perbedaan Fenomena Short-Term Undeprricing Dan Long-Term Underperformance Pada Saham Perusahaan BUMN Dan BUMS Yang Melakukan IPO Di BEI Tahun 2000-2010." Manajemen Atma (1):66-81.

Wong, Edward Sek, Ricky Wong WB, and Lee Sue Ting. 2017. "Initial Public Offering (IPO) Underpricing in Malaysian Settings." Journal of Economic \& Financial Studies 5(02):14. 